팽창흑연/에리스리톨 복합체의 열적거동에 관한 연구

\author{
최보경*** · 최웅기* · 국윤수* · 김홍건 ${ }^{* * \dagger} \cdot$ 서민강*, \\ *한국탄소융합기술원, **전주대학교 탄소융합공학과
}

(2014년 2월 20일 접수, 2014년 9월 10일 심사, 2014년 9월 12일 채택)

\title{
A Study on Thermal Behavions of Expanded Graphite/Erythritol Composites
}

\author{
Bo-Kyung Choi ${ }^{* * *}$, Woong-Ki Choi ${ }^{*}$, Yun-Su Kuk**, Hong-Gun Kim ${ }^{* *, \dagger}$, and Min-Kang Seo*, \\ ${ }^{*} R \& D$ Division, Korea Institute of Carbon Convergence Technology, Jeollabuk-do 561-844, Korea \\ **Department of Carbon Fusion Engineering, Jeonju University, Jeollabuk-do 560-759, Korea \\ (Received February 20, 2014; Revised September 10, 2014; Accepted September 12, 2014)
}

\begin{abstract}
초 록
본 연구에서는 팽창흑연의 함량 변화를 달리하여 제조한 팽창흑연/에리스리톨 복합체의 열적거동에 관하여 고찰하였 다. 팽창흑연이 도입된 팽창흑연/에리스리톨 복합체의 표면 및 구조특성은 scanning electron microscope (SEM), transmission electron microscope (TEM), 그리고 X-ray diffraction (XRD)를 이용하여 관찰하였으며, 열적특성은 differential scanning calorimetry (DSC)와 thermal conductivity (TC)를 이용하여 분석하였다. 실험 결과 팽창흑연의 함량이 증가함에 따라 팽창흑연/에리스리톨 복합체의 열전도도가 증가하였으며, 반면에 잠열은 팽창흑연의 존재 하에 약간 감소하였 다. 결론적으로 팽창흑연은 상변이 물질의 높은 열 전달성능 및 열 저장능력을 향상시키는데 적합한 소재라 판단된다.
\end{abstract}

\begin{abstract}
In this paper, the thermal behaviors of expanded graphite(EG)/erythritol composites with different contents of EG were studied. The surface and structure properties of the composites were determined by using scanning electron microscope (SEM), transmission electron microscope (TEM), and X-ray diffraction (XRD), respectively. The thermal properties were investigated by differential scanning calorimetry (DSC) and thermal conductivity (TC). As experimental results, the thermal conductivity of the composites increased with increasing the EG content. However, the latent heat was somewhat decreased in the presence of EG. We could concluded that EG was highly promising materials for improving the heat transfer enhancement and energy storage capacity of phase change materials (PCMs).
\end{abstract}

Keywords: phase change materials, expanded graphite, erythrital, latent heat, thermal conductivity

\section{1. 서 론}

에너지 저장장치는 열에너지의 저장손실을 최소화하여 에너지 효 율을 증가시키고 시스템의 비용 효율성을 개선하며 환경에 미치는 영 향을 줄여 에너지 절약에 도움이 되는 잠재력을 가지고 있기 때문에 현재, 에너지 저장 시스템 관련기술 개발이 활발히 이루어지고 있다 [1-6]. 이러한 열에너지 기술 가운데 가장 효과적인 방법 중 하나는 물 질의 상변화를 이용해 에너지를 저장하는 것이며 이러한 방법은 물질 의 현열이 아닌 잠열을 이용해 저장이 가능하기 때문에 고밀도로 에너 지를 저장할 수 있고, 일정한 온도에서의 축- 방열이 가능하다[7-8].

† Corresponding Author: H. G. Kim, Jeonju University, Department of Carbon Fusion Engineering, Jeollabuk-do 560-759, Korea / M. K. Seo, R\&D Division, Korea Institute of Carbon Convergence Technology, Jeollabuk-do 561-844, Korea

Tel: +82-63-219-3730 e-mail: hkim@jj.ac.kr, seomk721@kctech.re.kr

pISSN: 1225-0112 eISSN: 2288-4505@2014 The Korean Society of Industrial and Engineering Chemistry. All rights reserved.
상변이 물질 PCM (phase change materials)이란 하나의 상태에서 다 른 상태로 변하는 일정의 물리학적 과정을 이용하여 열을 축적하거나 저장한 열을 방출하는 상변화 과정을 통하여 많은 양의 열에너지를 축적하거나 방출하는 물질이다. 이러한 상변이 물질을 이용하여 잠열 을 저장하는 것은 다음과 같은 장점들이 있다. 첫째, 일반적으로 상변 이 물질의 잠열은 현열보다 50 100배 이상 높은 저장 밀도를 가지고 있다. 둘째, 상변이 물질은 폐열의 온도보다 약간 높은 온도에서 열에 너지를 생성할 수 있기 때문에 온도 저하와 열 회수에 용이하다. 셋째, 상변이 물질의 용융 및 응고 과정을 오랫동안 반복할 수 있다[9-10]. 따라서 이러한 여러 가지 장점 때문에 업계에서는 상변이 물질을 이 용하여 에너지 절감하는 사례가 늘어나고 있다. 이러한 장점에도 불 구하고 상변이 물질(PCM)을 열에너지 저장물질로 이용할 때 상변화 온도 부근에서 상변화를 나타내는 물질만 이용이 가능하며 낮은 전도 성으로 인하여 열전이 속도 저하가 일어나는 등의 문제점을 나타내는 것으로 알려져 있다. 이러한 단점을 극복하기 위한 방법으로 상변이 물질에 다양한 열전도성 첨가제를 첨가하여 열전도도를 높이는 방법 과 각 상변이 온도 영역에서 안정적으로 사용이 가능한 물질에 관한 
Table 1. Properties of Erythritol and EG

\begin{tabular}{ccc}
\hline & Erythritol & EG \\
\hline Density $\left(\mathrm{g} / \mathrm{cm}^{3}\right)$ & 1.28 & 1.3 \\
Thermal conductivity $(\mathrm{W} / \mathrm{mK})$ & 0.733 & $4-200$ \\
Latent heat $(\mathrm{J} / \mathrm{g})$ & 354.7 & 327 \\
Specific heat $(\mathrm{kJ} / \mathrm{kg} \cdot \mathrm{K})$ & 2.66 & - \\
Melting point $\left({ }^{\circ} \mathrm{C}\right)$ & $118-130$ & - \\
\hline
\end{tabular}

연구가 진행되어지고 있다[11-14]. 열전도성 첨가제를 첨가하는 방법의 경우 첨가제의 선정이 아주 중요한 요소인데 첨가제로는 expanded graphite (EG), nickel, carbon nanotube (CNT), expanded perlite (EP), diatom earth (DE), gamma-alumina (GA), carbon fiber, active carbon (AC), graphene oxide (GO) 등이 있다. 그중 expanded graphite (팽창흑연)는 다공성 구조를 나타내어 다양한 원자, 분자 그리고 이온 등이 흑연의 층 간에 삽입되어질 수 있어 층상화합물을 생성하며 빠른 열처리에 의해 쉽게 제조할 수 있으며, 소량을 사용하여도 열전도도가 높기 때문에 위 와 같은 문제를 해결하는데 도움이 될 것이라고 판단된다[15-20].

따라서, 본 연구에서는 저렴한 비용과 낮은 밀도를 가지고 열적 특 성이 우수하며 다공성을 갖는 팽창흑연과 잠열량이 크고 식품첨가제 로서 사용되고 있을 정도로 인체에 무해한 물질인 에리스리톨을 사용 하여 팽창흑연의 함량에 따른 팽창흑연/에리스리톨 복합체를 제조한 후 이에 대한 열적거동에 관하여 고찰하였다.

\section{2. 실 험}

\section{1. 재료}

본 실험에서 사용한 천연흑연(Aldrich, 평균직경 $>500 \mu \mathrm{m}$, 비중 2.09 2.23)은 flake상을 사용하였다. 층상화합물의 제조를 위하여 황 산(Mw : 98.08, DAEJUNG Chem.)과 질산(Mw : 63.01, DAEJUNG Chem.)을 정제 없이 사용하였고 에리스리톨은 Cargill Co.에서 순도 $99 \%, \mathrm{Mw}: 122.12$ 인 분말을 구입하여 사용하였다. 이에 대한 물성을 Table 1에 나타내었다[21].

\section{2. 팽창흑연 제조}

천연흑연의 산처리 및 열처리를 통한 층상화합물을 제조하기 위하 여 천연흑연을 황산/질산(4:1)의 혼합용액에 $24 \mathrm{~h}$ 동안 실온에서 침 적 처리하였다. 산처리에 의해 제조된 층상화합물을 증류수로 세척하 고 $90{ }^{\circ} \mathrm{C}$ 의 오븐에서 $8 \mathrm{~h}$ 동안 건조하였으며, 완전 건조 후 층상화합 물은 박스형 furnace에서 $900{ }^{\circ} \mathrm{C}$ 로 $90 \mathrm{~s}$ 동안 반응시켜 최종적으로 팽 창흑연을 제조하였다[22].

\section{3. 팽창흑연/에리스리톨 복합체 제조}

팽창흑연/에리스리톨 복합체는 $10 \mathrm{~g}$ 의 에리스리톨에 팽창흑연의 비 율을 5,10 그리고 $20 \%$ 로 달리하여 제조하였고 에리스리톨 내에 첨가 된 팽창흑연의 고른 분산을 위하여 약 5 10 min 동안 $120{ }^{\circ} \mathrm{C}$ 로 가열 하며 교반시켜 주었다. 얻어진 혼합물은 성형용 몰드에 채운 후 상온 에서 $5 \mathrm{~min}$ 동안 경화시켜 팽창흑연/에리스리톨 복합체를 제조하였 다. 이렇게 팽창흑연 함량을 달리하여 제조한 복합체를 pure erythritol, EG 5\%, EG $10 \%$, 그리고 EG $20 \%$ 라 각각 명명하였다.

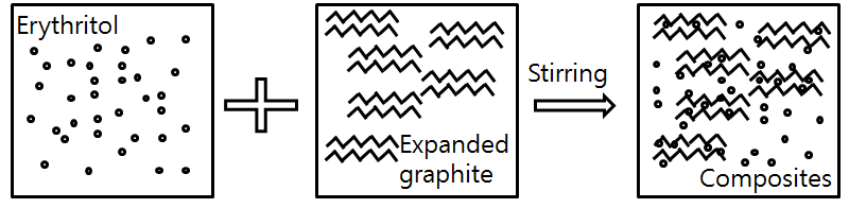

Figure 1. A mechanism showing the formation of EG/erythritol composites.

Figure 1은 에리스리톨 내에 필러로서 팽창흑연의 첨가에 의한 팽 창흑연/에리스리톨 복합체의 제조공정을 간략하게 나타낸 것으로서, 검은색 선은 팽창흑연을 나타낸다[23].

\section{4. 복합체의 표면 및 구조 특성}

팽창흑연/에리스리톨 복합체의 표면을 관찰하기 위해 전계방사형 주사전자현미경(FE-SEM, JSM-840A, JEOL, Japan)과 투과전자현미 경(FE-TEM, JEM-2100F, JEOL, Japan)을 사용하였다. 또한 팽창흑연/ 에리스리톨 복합체의 구조 변화를 측정하기 위하여 $\operatorname{CuK} \alpha(\lambda=$ $0.154 \mathrm{~nm}$ )를 장착한 $\mathrm{X}$-선 회절분석 $\left(\mathrm{XRD}, \mathrm{X}^{\prime}\right.$ PERT-MRD, Phillips Co., Netherlands) 장비를 이용하여 측정하였다.

\section{5. 팽창흑연/에리스리톨 복합체의 열적 특성}

팽창흑연/에리스리톨 복합체의 열전도도는 열전도율측정기(Thermo Con Tester M100, Metrotech Co., Ltd., Korea)를 사용하여 동일한 시편 으로 두께를 달리하여 5 회 측정한 후 평균값으로 열전도도를 구하였 다. 열전도율측정기는 ASTM D5470 규격의 열평형법을 이용해서 열 전도율을 측정하였다. 장치의 냉각부, 히팅부에는 구리봉을 사용하였 기에 상부, 하부의 열량이 평형이 되는 순간의 시편의 열전도율을 구 하는 것을 기준으로 하고 있으며, heat flow가 이루어진 상태에서의 총열량 $\mathrm{Q}$ 는 식 (1)로 구할 수 있다.

$$
Q=\frac{\lambda A}{d_{A}} \triangle T
$$

여기서, $\lambda$ 는 열전도율이며, $\mathrm{A}$ 는 구리봉의 면적, $\mathrm{d}_{\mathrm{A}}$ 는 구리봉의 거 리, $\Delta \mathrm{T}$ 는 구리봉에 밀착되어 있는 열전대간의 거리인 $\mathrm{d}_{\mathrm{A}}$ 사이의 온 도차를 나타낸다[24].

또한, 팽창흑연의 함량 변화에 따른 팽창흑연/에리스리톨 복합체의 열적특성을 측정하기 위하여 시차주사열량계(DSC, TA-60, SHIMADZU Co., Japan)를 사용하였으며, 승온조건 $10{ }^{\circ} \mathrm{C} / \mathrm{min}$ 으로 $150{ }^{\circ} \mathrm{C}$ 온도범 위까지 측정하였다.

\section{3. 결과 및 고찰}

\section{1. 팽창흑연 특성}

일반적으로 흑연은 탄소의 동소체로서 공유결합으로 연결된 탄소 원자들로 이루어져 있으며, 층상구조를 갖는다. 또한 흑연의 각 층들 은 다른 층과 평행한 배열을 이루고 있으며 각 층간은 공유 결합으로 연결된 탄소원자보다 약한 van der Waals 힘에 의해 결합되어 있다. 이러한 특성으로 흑연의 층간 사이에는 다양한 원자 또는 분자가 삽 입될 수 있어 쉽게 층상화합물을 형성할 수 있다[25].

Figure 2는 천연흑연과 황산/질산의 산처리 및 열처리에 의해 제조 된 팽창흑연의 SEM 사진을 나타낸 것이다. Figure 2(a)에서 보는 바 
Table 2. Interlayer Distance $\left(\mathrm{d}_{002}\right)$ of Natural Graphite and EG

\begin{tabular}{ccc}
\hline & Natural graphite & EG \\
\hline $\begin{array}{c}\text { Interlayer distance } \\
\left(\mathrm{d}_{002}\right)(\AA)\end{array}$ & 3.35 & 3.37 \\
\hline
\end{tabular}

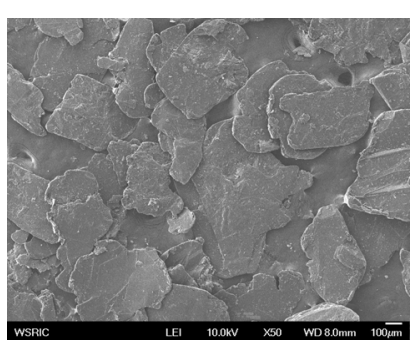

(a)

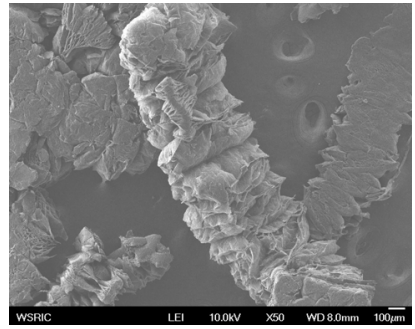

(b)
Figure 2. SEM images of natural graphite (a) and EG (b).

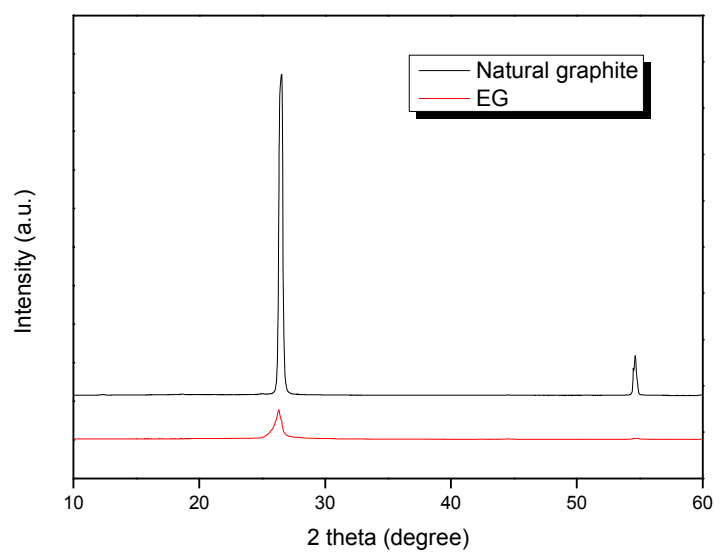

Figure 3. XRD pattems of natural graphite and EG.

와 같이 각기 다른 크기를 갖는 판상의 천연흑연은 산처리와 열처리 에 의하여 Figure 2(b)와 같은 기공형상을 갖는 팽창흑연을 생성하고, 약한 결합을 갖는 흑연의 c-축이 팽창되어 부풀어 오른 zig-zag 구조 의 'worm-like'의 형태를 나타내었다. 이렇게 제조된 팽창흑연은 팽창 에 의하여 천연흑연보다 낮은 비중과 높은 종횡비, 그리고 커다란 반 응 비표면적에 의하여 우수한 물성을 나타낸다[26].

\section{2. 팽창흑연의 구조}

Figure 3은 천연흑연과 팽창흑연에 대한 XRD 결과이며 산처리 및 열처리 전후의 흑연의 층간거리를 비교하기 위하여 이들 XRD 곡선으 로부터 팽창흑연의 층간거리 $\left(\mathrm{d}_{002}\right)$ 값을 구하였다. 팽창흑연의 층간거 리는 Bragg's 법칙의 XRD 곡선의 (002) 피크에서 구한 $\mathrm{d}_{002}$ 층간거리 는 아래 식 (2)을 이용하였다[27].

$\mathrm{n} \lambda=2 \mathrm{~d} \cdot \sin \theta$

여기서 $\mathrm{n}$ 은 정수, $\lambda$ 는 $\mathrm{X}$-선의 파장, $\mathrm{d}$ 는 팽창흑연의 층간거리이며, $\theta$ 는 회절각도를 나타낸다.

Table 2에 나타낸 바와 같이 산처리와 열처리에 의하여 팽창흑연의 층간거리가 천연흑연에 비해 더 넓어진 것을 알 수 있었다. 그리고

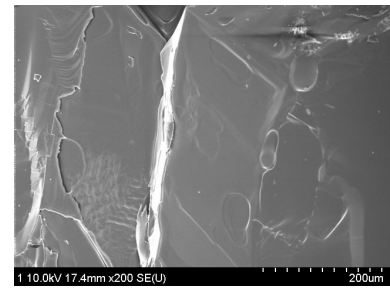

(a)

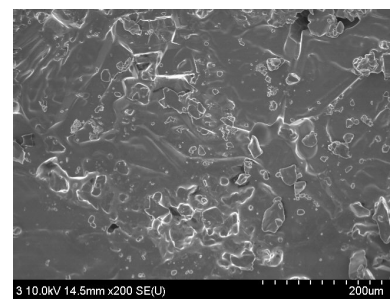

(c)

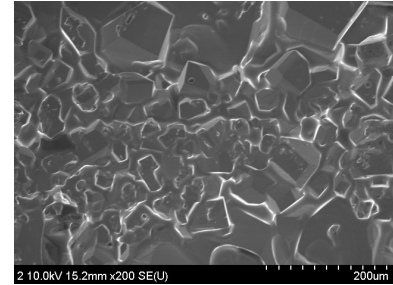

(b)

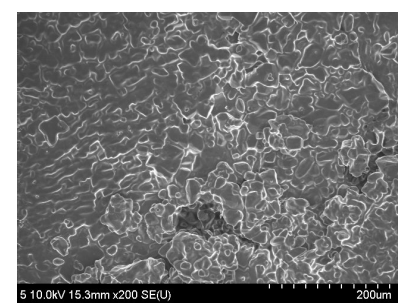

(d)
Figure 4. SEM images of EG/erythritol composites as a function of EG content; (a) pure enythritol, (b) EG 5\%, (c) EG 10\% and (d) EG 20\%

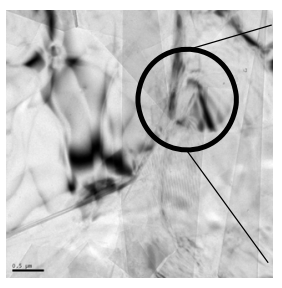

(a)

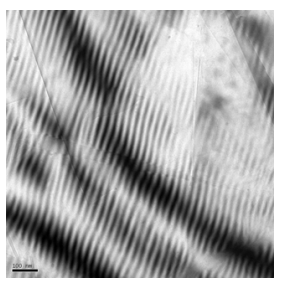

(b)

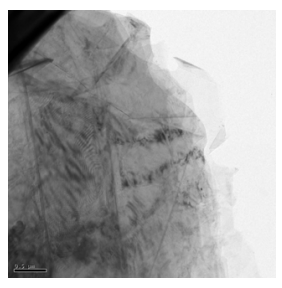

(c)
Figure 5. TEM images of EG/erythritol composites as a function of EG; (a, b) EG, and (c) EG $20 \%$

Figure 3 에서 보는 바와 같이 천연흑연은 $2 \theta 26^{\circ}$ 와 $54^{\circ}$ 부근에서 흑연 의 특정 피크를 나타내었으며, 각각의 평행한 층들은 매우 높은 결정 성을 가지고 있는 것을 확인할 수 있었다. 또한 $26^{\circ}$ 부근의 피크가 산 처리 후 board해지고 왼쪽으로 이동하였으며, $55^{\circ}$ 부근 피크의 강도가 약해지는 등 천연흑연의 특성 피크가 변화된 것을 알 수 있었다. 즉 산 처리 및 열처리를 통하여 천연흑연의 결정성 저하 및 특성 피크의 강 도가 약해짐을 확인하였는데[28], 이는 천연흑연을 적절한 처리를 통 하여 다공성 구조를 갖는 팽창흑연으로 제조 가능함을 알 수 있었다.

\section{3. 표면 및 구조 특성}

Figure 4는 팽창흑연의 함량에 따라 제조된 팽창흑연/에리스리톨 복합체의 SEM 사진을 나타낸 것이다. 팽창흑연의 함량이 증가함에 따라 표면이 점점 조밀하게 되는 것을 확인하였다. 이는 에리스리톨 의 표면에 팽창흑연이 부착하여 조밀하고 불균일한 상을 형성하게 되 는 것으로 판단된다.

Figure 5는 팽창흑연과 팽창흑연/에리스리톨 복합체의 TEM 사진으 로서 상변이 물질의 성능 발현이 제대로 일어나려면 물질 내부에서의 분산이 고르게 되어 있어야 하는데, Figure 5(c)에서 알 수 있듯이 열 적 안정성을 가지고 있는 팽창흑연은 엉킴 없이 잘 분산되어 있는 것 을 확인하였다.

팽창흑연/에리스리톨 복합체의 XRD 결과를 Figure 6에 나타내었 다. 팽창흑연/에리스리톨 복합체 내에 팽창흑연의 함량이 증가할수록 


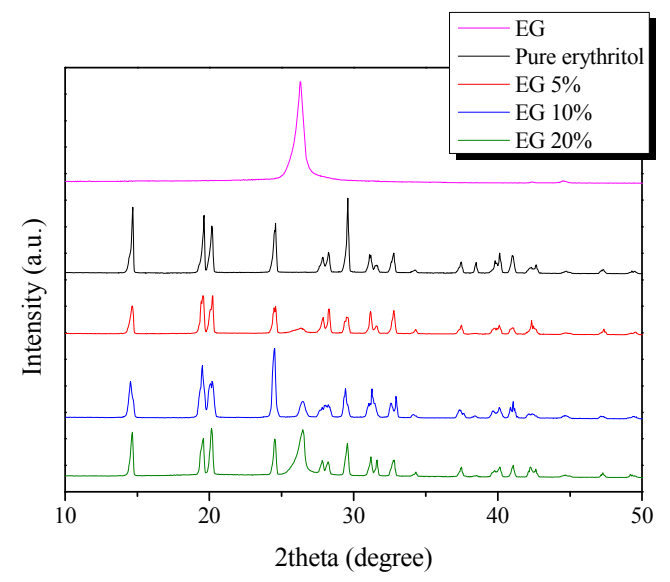

Figure 6. XRD pattems of EG/erythritol composites as a function of EG content.

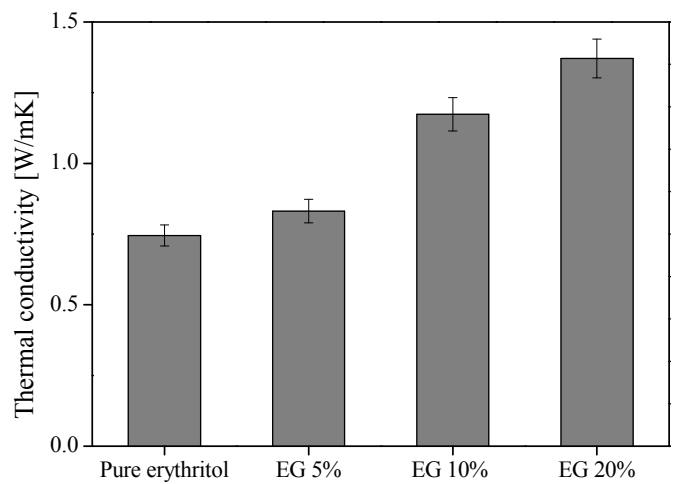

Figure 7. Thermal conductivity of EG/erythritol composites as a function of EG content.

에리스리톨의 결정성은 감소되고 흑연 피크인 $26^{\circ}$ 부근의 피크가 증가 함을 확인하였다. 이는 팽창흑연이 첨가됨에 따라 에리스리톨의 결정 성 영역의 성장을 억제하며, 이로 인하여 전체적인 피크 세기의 감소, 즉 에리스리톨의 결정화도가 작아짐을 확인하였다[29].

\section{4. 열적 특성}

Figure 7은 순수 에리스리톨 및 팽창흑연/에리스리톨 복합체의 열 전도도를 측정하여 평균치를 구한 결과이다. 순수한 에리스리톨로 제 조된 복합체에 비해 팽창흑연/에리스리톨 복합체의 열전도도가 높게 관찰되었다. 특히 팽창흑연 $20 \%$ 를 첨가하였을 경우 순수 에리스리톨 보다 약 $84 \%$ 향상되어 팽창흑연/에리스리톨 복합체에서 열전도도의 향상효과가 뛰어난 것을 확인하였다. 이는 팽창흑연이 에리스리톨 내 에서 효과적인 분산이 이루어졌고 팽창흑연 자체의 우수한 열전도성 의 기여가 큰 것으로 판단된다. 또한 팽창흑연의 함량이 증가할수록 팽창흑연이 차지하는 표면적이 넓어지고 서로 간에 접촉이 많아져 열 이 이동할 수 있는 통로가 많아지게 되면서 열전달 경로를 형성하는 것으로 보여 팽창흑연의 함량에 따라 복합체의 열전도도는 일정하게 증가됨을 알 수 있었다[30-31].

Figure 8에 DSC를 이용하여 측정한 팽창흑연/에리스리톨 복합체의 열분석 결과와(Figure $8(\mathrm{a})$ ), 이를 흡열피크의 면적으로 측정하여 분석 한 잠열 결과(Figure 8 (b))를 나타내었다. 결과에 나타낸 바와 같이 에
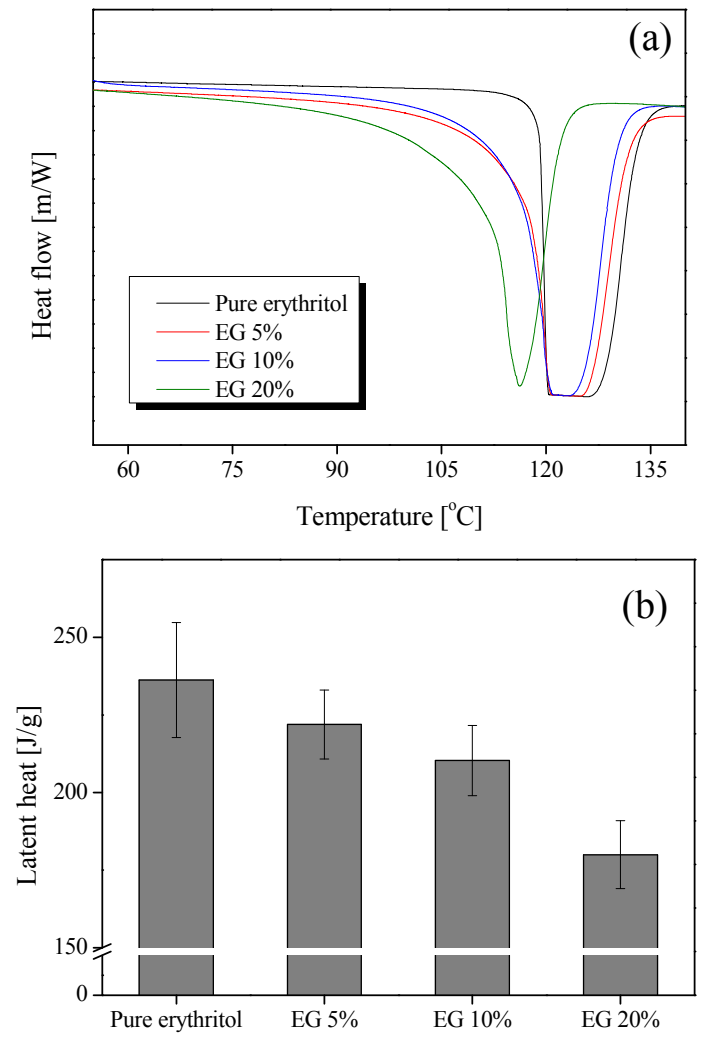

Figure 8. DSC curvs (a) and latent heat (b) of EG/enythritol composites as a function of EG content.

리스리톨은 융점이 $125.2{ }^{\circ} \mathrm{C}$, 잠열 $236.22 \mathrm{~J} / \mathrm{g}, \mathrm{EG} 5 \%$ 복합체는 126.5 ${ }^{\circ} \mathrm{C}$ 에서 $221.92 \mathrm{~J} / \mathrm{g}, \mathrm{EG} 10 \%$ 복합체는 $123.2{ }^{\circ} \mathrm{C}$ 에서 $210.31 \mathrm{~J} / \mathrm{g}, \mathrm{EG}$ $20 \%$ 복합체는 $116.2{ }^{\circ} \mathrm{C}$ 에서 $179.99 \mathrm{~J} / \mathrm{g}$ 의 잠열량을 가지는 데이터를 얻었다. 순수 에리스리톨 보다 팽창흑연을 가장 많이 첨가한 EG $20 \%$ 의 결과에서는 피크온도 $9{ }^{\circ} \mathrm{C}$ 가 저하, 융해되었고 잠열값도 약 $23.80 \%$ 줄어든 것을 확인하였다. 이러한 현상은 상변이 고분자 재료 에 열전도도가 우수한 다른 재료를 혼합한 경우 고분자 재료의 분자 배열 사이에 다른 물질이 들어감으로서 응고 시에 방해를 받게 되고, 또한 분자 사이의 상호작용의 힘이 작아지기 때문에 복합재료의 융점 저하가 일어난다고 판단된다[32]. 그러나 에리스리톨 내의 팽창흑연 함량 증가는 높은 열전달을 위한 효과적인 네트워크를 형성하며, 열 이 빠르게 이동할 수 있는 전달 경로를 증가시켜 열을 축적하거나 저 장한 열을 방출하는 상변화 물질로 사용 가능함을 확인하였다.

\section{4. 결 론}

본 연구에서는 팽창흑연의 함량을 달리하여 제조한 팽창흑연/에리 스리톨 복합체의 열적특성을 고찰하였다. 그 결과 팽창흑연이 첨가됨 에 따라 팽창흑연/에리스리톨 복합체는 순수한 에리스리톨에 비해 열 전도도 값이 약 $84 \%$ 가 증가하였으나 잠열은 약간 감소한 것을 알 수 있었다. 또한, 팽창흑연 함량이 가장 높은 EG $20 \%$ 의 경우가 가장 높 은 열전도도 값을 나타냄을 확인하였다. 이러한 결과로부터 에리스리 톨 내의 팽창흑연 함량의 증가는 높은 열전달을 위한 효과적인 네트 워크를 형성하며, 이에 따른 표면적의 증가는 접촉면이 증가되어지는 결과를 야기하며, 열이 빠르게 이동할 수 있는 전달 경로의 증가로 이 
어진다. 따라서, 팽창흑연/에리스리톨 복합체는 열을 효율적으로 저장

및 방출할 수 있는 상변이 물질로서 활용 가능하다고 판단된다.

\section{감 사 \\ 본 연구는 에너지기술개발사업(SUBJID_0000000014701)의 지원에 의하여 수행하였으며 이에 감사드립니다.}

\section{References}

1. T. Nomura, N. Okinaka, and T. Akiyama, Impregnation of porous material with phase change material for thermal energy storage, Master. Chem. Phys., 115, 846-850 (2009).

2. F. Frusteri, V. Leonardi, and G. Maggio, Numerical approach to describe the phase change of an inorganic PCM containing carbon fibers, Appl. Therm. Eng., 26, 1883-1892 (2006).

3. A. Karaipekli, A. Sari, and K. Kaygusuz, Thermal conductivity improvement of stearic acid using expanded graphite and carbon fiber for energy storage applications, Renew. Energy, 32, 2201-2210 (2007).

4. S. Pincemin, R. Olives, X. Py, and M. Christ, Highly conductive composites made of phase change materials and graphite for thermal storage, Sol. Energy Mater. Sol. Cells, 92, 603-613 (2008).

5. Y. J. Chen, D. D. Nguyen, M. Y. Shen, M. C. Yip, and N. H. Tai, Thermal characterizations of the graphite nanosheets reinforced paraffin phase-change composites, Compos. A, 44, 40-46 (2013).

6. D. Haillot, T. Bauer, U. Kröner, and R. Tamme, Thermal analysis of phase change materials in the temperature range $120-150^{\circ} \mathrm{C}$, Thermochim. Acta, 513, 49-59 (2011).

7. F. Kang, Y. P. Zhang, H. N. Wang, Y. Nishi, and M. Inagaki, Effect of preparation conditions on the characteristics of exfoliated graphite, Carbon, 40, 1575-1581 (2002).

8. G. Chen, C. Wu, W. Weng, D. Wu, and W. Yan, Preparation of polystyrene/graphite nanosheet composite, Polymer, 44, 1781-1784 (2003).

9. P. M. Gilart, A. Y. Martinez, M. G. Barriuso, and C. M. Martinez, Development of PCM/carbon-based composite materials, Sol. Energy Mater. Sol. Cells, 107, 205-211 (2012).

10. S. J. Park, K. S. Kim, and S. K. Hong, Preparation and thermal properties of polystyrene nanoparticles containing phase change materials as thermal storage medium, Polymer(Korea), 29, 8-13 (2005).

11. S. W. Yim, J. H. Lee, Y. G. Lee, S. G. Lee, and S. R. Kim, Effect of the pressure on the interface and thermal conductivity of polypropylene-SiC composites, J. Adhes. Interface, 10, 30-34 (2009).

12. J. H. Hong and S. E. Shim, Trends in development of thermal conductive polymer composites, Appl. Chem. Eng., 21, 115-128 (2010).

13. W. L. Cheng, N. Liu, and W. F. Wu, Studies on thermal properties and thermal control effectiveness of a new shape-stabilized phase change material with high thermal conductivity, Appl. Therm. Eng., 36, 345-352 (2012).

14. Z. Chen, F. Shan, L. Cao, and G. Fang, Synthesis and thermal properties of shape-stabilized lauric acid/activated carbon composites as phase change materials for thermal energy storage, Sol. Energy Mater. Sol. Cells, 102, 131-136 (2012).

15. M. Mehrali, S. T. Latibari, M. Mehrali, H. Metselaar, and M. Silakhori, Shape-stabilized phase change materials with high ther- mal conductivity based on paraffin/graphene oxide composite, Energy Convers. Manage., 67, 275-282 (2013).

16. T. P. Teng, C. M. Cheng, and C. P. Cheng, Performance assessment of heat storage by phase change materials containing MWCNTs and graphite, Appl. Therm. Eng., 50, 637-644 (2013).

17. V. D. Bhatt, K. Gohil, and A. Mishra, Thermal energy storage capacity of some phase changing materials and ionic liquids, Int. J. Chemtech. Res., 2, 1771-1779 (2010).

18. X. Xiao, P. Zhang, and M. Li, Thermal characterization of nitrates and nitrates/expanded graphite mixture phase change materials for solar energy storage, Energy Convers. Manage., 73, 86-94 (2013).

19. F. Frusteri, V. Leonardi, S. Vasta, and G. Restuccia, Thermal conductivity measurement of a PCM based storage system containing carbon fibers, Appl. Therm. Eng., 25, 1623-1633 (2005).

20. S. Y. Lee, H. K. Shin, M. R. Park, K. Y. Rlee, and S. J. Park, Thermal characterization of erythritol/expanded graphite composites for high thermal storage capacity, Carbon, 68, 67-72 (2014).

21. T. Oya, T. Nomura, M. Tsubota, and N. Okinaka, and T. Akiyama, Thermal conductivity enhancement of erythritol as PCM by sung graphite and nickel particles, Appl. Therm. Eng., 61, 825-828 (2013).

22. L. Xia, P. Zhang, and R. Z. Wang, Preparation and thermal characterization of expanded graphite/paraffin composite phase change material, Carbon, 48, 2538-2548 (2010).

23. S. J. Park, K. S. Kim, and J. R. Lee, Thermal and mechanical interfacial properties of expanded graphite/epoxy composites, $J$. Korean Ind. Eng. Chem., 15, 493-498 (2004).

24. J. R. Choi, Y. S. Lee, and S. J. Park, Influence of electroless Ni-plated MWCNTs on thermal conductivity and fracture toughness of MWCNTs $/ \mathrm{Al}_{2} \mathrm{O}_{3}$ /epoxy composites, Polymer(Korea), 37, 449-454 (2013).

25. S. J. Park and K. S. Kim, A study on oil adsorption of expanded gaphites, Korean Chem. Eng. Res., 42, 362-367 (2004).

26. S. M. Kim and L. T. Drzal, High latent heat storage and high thermal conductive phase change materials using exfoliated graphite nanoplatelets, Sol. Energy Mater. Sol. Cells, 93, 136-142 (2009).

27. D. H. Choi, J. H. Lee, H. R. Hong, and Y. T. Kang, Thermal conductivity and heat transfer performance enhancement of phase change materials (PCM) containing carbon additives for heat storage application, Int. J. Refrigeration, 42, 112-120 (2014).

28. S. J. Park, K. S. Kim, and S. K. Hong, Preparation and characterization of expanded graphites by wet process, Hwahak Konghak, 41, 802-807 (2003).

29. C. Wang, L. Feng, W. Li, J. Zheng, W. Tian, and X. Li, Shape-stabilized phase change materials based on polyethylene glycol/porous carbon composite: The influence of the pore structure of the carbon materials, Sol. Energy Mater. Sol. Cells, 105, 21-26 (2012).

30. A. Sari and A. Karaipekli, Fatty acid esters-based composite phase change materials for thermal energy storage in building, Appl. Therm. Eng., 37, 208-216 (2012).

31. T. Oya, T. Nomura, N. Okinaka, and T. Akiyama, Phase change composite based on porous nickel and erythritol, Appl. Therm. Eng., 40, 373-377 (2012).

32. J. S. Yu, A. Horibe, N. Haruki, and M. J. Kim, Melting \& solidification characteristic on mixture of erythritol and mannitol of latent heat storage material, Trans. Korean Soc. Mech. Eng., 11, 807-812 (2012). 